\title{
Refah Devleti: İslam Ekonomisi Açısından Bir Eleştiri
}

\author{
Harun Şencal ${ }^{*}$
}

Merve Reyhan Ekinci**

\author{
Received: 05.07.2021 \\ Accepted: 28.10.2021 \\ DOI: $10.25272 /$ ijisef.962973 \\ Type: Research Article
}

Öz

Bu çalışmanın iki ana hedefi bulunmaktadır. İlk olarak refah devletinin temel yapısı ve bu yapının toplumsal bağlamda nasıl sonuçlar doğurduğu incelenecektir. Bu analizden sonra ikinci olarak, özgürleştirme (emancipation) ve güçlendirme (empowerment) kavramları bağlamında refah devletinin İslam ekonomisi açısından eleştirel bir analizi yapılacaktır. Bu bağlamda, bireylerin iyi vatandaşlar olmasını sağlayan iki temel noktaya değinilecektir. İlki, refah devletlerinin yeniden dağıtım mekanizmasını merkezden kontrol etmesi sayesinde, refahın kimlere ve nasıl ulaştırılacağını belirleyebilmesidir. İkinci olarak, refahtan payını alma motivasyonunun yanı sıra, refah devletinin ücretsiz olarak sunduğu eğitim imkanlarıdır, yani okul kurumu sayesinde bireylerin küçük yaştan itibaren iyi bir vatandaş olmak üzere yetişmesi ve iyi bir vatandaş olmanın gereklerini içselleştirmesidir. Refahtan payını alabilmek için dışsal bir motivasyonla veya okul kurumu aracılığıyla içselleştirdiği dahili bir motivasyonla itaatkar bir vatandaş olmak, bireylerin özgürlüklerinden -önemli ölçüdevazgeçmesi anlamına gelmektedir. Merkezi bir şekilde sunulan refah bireylerin özgürlüğünü ellerinden alırken; eğitim, sağlık ve maddi destek gibi birçok ihtiyacın devlet eliyle sunulması, sivil toplumun organize olarak siyasi otoriteden bağımsız bir güç oluşturmasının ve bireylerin, devletin sunduğu imkanlardan bağımsız, özerk bir alan oluşturmalarının önüne geçmektedir. Bu sebeple, bireyler güçlerini iyi bir vatandaş oldukları müddetçe devletin sunduğu imkanlar sayesinde alırlar. Diğer bir ifadeyle, iyi bir vatandaş oldukları ölçüde güçlü olmaktadırlar. Halbuki, İslam ekonomisinin tahayyül ettiği siyasi yönetimde mükelleflerin özgürlüğünden mahrum ve güçsüz bir konumda bulunmaması esastır. İyiyi emredebilen ve karşılaşılan münkerleri çekinmeden menedebilen mükellefler ancak böyle bir toplumda bulunabilir. Bunu sağlayabilmek için de İslami özellikleri haiz bir toplumsal yapıda inşa edilecek eğitim ve adalet kurumlarının; mükellefleri merkezi bir güce bağımlı kılan değil, Allah'a olması gerektiği gibi ibadet edebilecek kullar olması için gerekli bilgi, beceri ve gücü sunan kurumlar olması gerekir.

Anahtar Kelimeler: Refah Devleti, İslam Ekonomisi, Özgürlük, Güçlendirme, Okul

Jel Kodlar1: D60, H53, P36

\section{The Welfare State: A Criticism from the Perspective of Islamic Economics}

\section{Abstract}

This study has two main objectives. First, the basic structure of the welfare state and how this structure has consequences in the social context will be examined. After this analysis, secondly, a critical analysis of the welfare state from the perspective of Islamic economics will be made in the context of the concepts

* Dr. Öğr. Üyesi, İstanbul 29 Mayıs Üniversitesi, harun.sencal@gmail.com, ORCID: 0000-0003-3617-8954

** Yüksek Lisans Öğrencisi, İbn Haldun Üniversitesi, reyhan.eknc@gmail.com, ORCID: 0000-0003-09749598 
of emancipation and empowerment. In this context, we discussed two main points that make individuals good citizens. The first is that welfare states can determine to whom and how welfare will be delivered, thanks to the central control of the redistribution mechanism. Secondly, in addition to the motivation to get their share of welfare, individuals grow up to be good citizens from a young age and internalize the requirements of being a good citizen through the educational institutions provided by the welfare state free of charge, namely the school institution. Being an obedient citizen with an extrinsic motivation or an internal motivation internalized through the school institution to get a share of welfare means that individuals give up their freedom to a significant extent. Centrally delivered welfare significantly deprives individuals of their freedom; the provision of many needs such as education, health and financial support by the state prevents the civil society from forming an organized power independent from the political authority and individuals from forming an autonomous space independent of the opportunities offered by the state. For this reason, individuals get their power through the opportunities offered by the state as a result of being good citizens. In other words, they become powerful to the extent that they are good citizens. However, in the political governance envisioned by the Islamic economy, it is essential for obligants (mukallaf) not to be deprived of their freedom and in a powerless position. Only in such a society, obligants who are able to enjoin good and forbid wrong without hesitation can be encountered. In order to achieve this, educational and justice institutions which will be built in a social structure with Islamic features should be institutions that offer the necessary knowledge, skills and power to be servants who can worship Allah as they should be, rather than making obligants dependent on central power.

Keywords: Welfare State, Islamic Economics, Emancipation, Empowerment, School

Jel Codes: D60, H53, P36 


\section{Giriş}

Birçok sosyal bilimciye göre 19. yüzyıl hayatımızda geri dönülmez ve tanımlanması bugün bile zor olan birçok değişikliklere sahne oldu. Her yerde ve her toplulukta gizemli bir şehir efsanesiymiş gibi her an konuşulan ve tartışılan olgularımız ortaya çıkmaya başladı. Bu olgulara kapitalizm, serbest piyasa, millet, ulus-devlet gibi kavramları örnek verebiliriz. Sosyal refah devleti de -diğerlerine kıyasla daha genç bir olgu olsa da- bu olguların arasında bulunmaktadır. Refah devleti, daha adı konulmadan önce bile devletin şu veya bu konuda ne yapması gerektiği üzerinden hep tartışılagelen bir olgu olarak karşımıza çıkar. Refah devleti temel alınan ideolojiye göre değişkenlik gösterir; bir yandan muhafazakar siyasetçiler için sosyalizme karşı bir panzehir olarak görülürken diğer taraftan sosyalizmin, kapitalizm karşısında attı̆̆ bir adım olarak addedilmektedir (Wahl, 2015). Hangi ideolojinin başarısı olduğundan bağımsız olarak iddia edebiliriz ki refah devleti; liberal toplumlarda piyasa tarafından şekillenmesi beklenen bireysel ve toplumsal ilişkilerde merkezi bir güç olarak düzenleyici ve müdahaleci bir aktör olarak rol almaya başlamış ve vatandaşların refahı için bazı hizmetleri piyasaya bırakmak yerine yeniden dağıtım mekanizması sayesinde daha eşitlikçi şekilde vatandaşlarına ulaştırmayı hedeflemiştir.

Refah devleti eğitim başta olmak üzere merkezi olarak kontrol ettiği kurumlar sayesinde hem sınırları içerisinde kurallara uyacak "vatandaş"1 hem de refah üretimine katkı sağlayacak "işçi” yi yetiştirmektedir. Böylece piyasa karşısında konumlanan bir aktör olarak refah devleti, merkezi bir güç oluşturmuş ve sunduğu refahın karşılığında, hem bu refah düzeninin devamını garanti altına almak için hem de merkezi gücünü devam ettirebilmek için vatandaşların hayatına -dolaylı veya doğrudan- müdahale etme gücüne sahip olmuştur. Bunun neticesinde, devlete bağlı ve bağımlı yaşamlarını sürdüren vatandaşlar üreten refah devletleri, geleneksel toplumlarda bulunan bireyler arasındaki dayanışma ve yardımlaşmayı merkezden sağlayarak bireyselleşmenin önünü açmıştır. Refah devletinin sunduğu imkanlar sayesinde herhangi bir sıkıntı yaşamadan hayatını idame ettirebilecek vatandaşların yapması gereken tek şeyin "iyi vatandaş" olmaktan geçmesinden ötürü, bu imkanlara sahip olmak için itaat etmeli ve özgürlüklerinden -önemli derecede- feragat etmelidirler. Aksi takdirde, vatandaşlar refah devletinin imkanlarından yararlanamadıkları gibi refah devleti toplumsal dayanışma ve yardımlaşma kurumlarının yerini alacak, başvurulacak alternatif kurumlar azalacaktır. Özgürlüğün yanı sıra, kapitalist sistem içerisinde devletten ve devletin kurumlarından bağımsız olarak varlığını sürdürecek güç ve yetki bireysel ve topluluk düzeyinde vatandaşlara verilmediği için devletin gücünün ve kurumlarının tahakküm etmediği bir alanda yaşamak da ayrıca zor olacaktır.

Refah devletinin sunduğu imkanlardan yararlanabilmek karşılığında vatandaşların nelerden vazgeçmesi gerektiğini İslam ekonomisi açısından inceleyen bu çalışmanın iki ana hedefi bulunmaktadır. İlk olarak refah devletinin temel yapısı ve bu yapının toplumsal bağlamda nasıl sonuçlar doğurduğu incelenecektir. Bu analizden sonra ikinci olarak, özgürleştirme (emancipation) ve güçlendirme (empowerment) kavramları aracılı̆̆ı ile refah devletinin İslam ekonomisi açısından eleştirel bir analizi yapılacaktır. Ayrıca, refah devletinde merkezi 
otoritenin üstlendiği yeniden dağıtım mekanizmasının Müslüman toplumlarda sivil toplum tarafından yapılmasını sağlayan zekat, sadaka ve kurban gibi kurumların refah devleti ile ilişkisi ve netice itibariyle toplumsal ilişkiler bağlamında nasıl bir farklılık oluşturduğu araştırılacaktır. Bu çalışma ile son yıllarda tartışmaların odağında olan refah devleti, İslam ekonomisinin belirli perspektiflerinden incelenmiş ve böylece konuya iki yönlü bir açılım getirilmiş olacaktır.

\section{Sosyal Refah Devletinin Tarihi Arka Planı}

Yaşamımızın bir parçasını oluşturan birçok olgunun ortak ve genel bir tanımının yapılması çok zor hatta birçok düşünüre göre imkânsızdır. Sosyal refah devleti için de bu kaide geçerlidir. Zira, literatürde birçok tanımı bulunmakta ve her geçen gün değişen hayat standartları nedeniyle bu tanımlar değişmektedir. Zaten değişen toplum şartlarının ortaya çıkardığı bir sistemin, toplum değişmeye devam ettikçe aynı kalması beklenmemelidir. Gümüşüun (2018, s. 35) ifadesiyle, "her devlet türü kadar farklı 'refah devleti' vardır denilebilir." Fakat bu değişimlerin etkisini irdeleyebilmek için öncelikle refah devletinin tarihsel arka planına bakarak onu anlamak gerekmektedir.

Refah devleti teriminin ilk kullanımına dair Gümüş'ün (2018, s. 34) ifade ettiği aşağıdaki bilgiler, bu kavramın gayet yararcı ve siyasi amaçlarla ortaya çıktığını göstermektedir:

'Refah devleti' terimi İngiltere'de, ilk defa İkinci Dünya Savaşı döneminde, 'savaş devleti' olarak görülen Nazi Almanya'sı ile Nazi Almanya'sı tehdidine karşı neredeyse tek başına ayakta durmaya çalışan İngiltere arasındaki zıtlığı ortaya koyabilmek adına 1941 yılında kullanılmıştır. Yani, terimin ortaya atılışı devletin sosyalliğini vurgulamaktan ziyade, savaş zamanında moralleri yüksek tutmak ve disiplini sağlayabilmek için olmuştur.

Wahl (2015) ise, söylemin ötesinde bir uygulama olarak refah devletinin ortaya çıkmasıyla ilgili Rus Devrimi ve yayılmakta olan sosyalizme karşı refah devletinin zaruri bir önlem olarak kullanılmasına dikkat çeker. Bunun yanı sıra, refah devletinin ortaya çıkışında ekonomik sebeplerin de etkili olduğunu belirten Wahl (2015), üç genel refah devlet modelinden biri olan Bismarck Modelinin de temel çıkış amaçlarından birisinin, fabrikalarda çalışacak emek gücünün azalmasını önlemek olduğuna değinir.

Refah devletlerinin ilk politikalarına baktığımızda, önceleri sadece çalışmakta olan -genelde erkek- işçileri özellikle sağlık alanında kapsadığını, işçilerin aileleri için geçerli olmadığını görmekteyiz (İ. Gümüş, 2018). Bu bilgilerden sonra şu sonuca varılabilir: aşırı sanayileşme sonrası iş̧̧ilerin hayat şartlarının kötüleşmesi, devlet müdahalesini asgaride tutan klasik iktisadi anlayışın 1929 Buhranını düzeltmede yetersiz kalması, bunun sonucunda kapitalist sistemle birlikte kontrol edilemeyecek derecede ilerlemiş olan piyasa güçlerini ve bu güce karşı yükselen dönemin sosyalist, emekçi seslerini kontrol altına alabilmek, var olan işgücü potansiyelini korumak isteği refah devletlerinin temel çıkış ve yükseliş sebepleridir (Briggs, 1961; A. T. Gümüş, 2010; İ. Gümüş, 2018). 
Refah devletini öncesiyle birlikte değerlendirmek ve değişimin ne zaman, ne sebeple geliştiğini anlamak için tarihi seyre kısaca göz atmak faydalı olacaktır. Tarihi akış içerisinde toplumlara bakıldığında sanayi devrimi öncesi dönemde insanlar ziraat, ticaret ya da bir zanaat ile uğraşarak yaşamlarını idame ettirir ve geleneksel toplumlarda kişiler çalışabildiği yaşa kadar çalışır, sonrasında ise aileleri tarafından bakımları sağlanırdı. Bunun mümkün olmadığı şartlarda ise devreye vakıflar, yardım kuruluşları ya da yöneticiler girerdi. Haliyle geleneksel toplumlarda emeklilik ya da işsizlik maaşı kavramlarının pek de bir karşılık bulamayacağını iddia edilebilir. Eğitim söz konusu olduğunda ise genel itibariyle usta-çırak ilişkisi ile kişilerin kendileri için gerekli olan bilgi öğrenilmekteydi.

Sanayileşme ile birlikte ekonomik sistem ve kullanılan araçlar değişmekle kalmamış aynı zamanda toplum da değişime uğramıştır (Polanyi, 2001). Çalışma şekli ve zamanları gündelik hayattaki birçok alışkanlığı ve geleneği değiştirmeye ve kendine uyarlamaya başlamıştır. Bir başka ifadeyle, sanayileşme ile ekonomik büyüme göstermeye başlayan kapitalist sistem kendi ihtiyaçlarını üretirken o ihtiyaçları karşılayacak alanları da üretmiştir. Örneğin disiplinli işçi ihtiyacını karşılamak için toplumu okullaştırırken (Illich, 2013), kapitalist girişimlerin güvenliğini sağlamak için de polis teşkilatının kurulmasında etkin olmuştur (Johnson, 2014). Fakat serbest piyasa ekonomisinin modern öncesi dönemde olduğu gibi topluma mündebiç (embedded) olarak faaliyet göstermek yerine, toplumu şekillendiren bir sistem haline dönüşmesi son aşamada karşı hareketlere (counter-movement) yol açarak (Polanyi, 2001) sosyal refah devletinin ortaya çıkmasına yol açmıştır (Luhmann, 2002). Özellikle uzun saatler ve yoğun bir şekilde çalışmak zorunda kalan işçiler (hatta çocuk işçiler), verimlilik ve düşük maliyet esasına dayalı olarak şekillendirilmeye çalışılan iş hayatı ve toplumsal ilişkiler devletin müdahale etmediği takdirde kapitalist sistemin toplumu çok olumsuz etkileyeceği distopik bir hal almaya başlamıştı (Polanyi, 2001).

Her ne kadar bazı kaynaklarda sosyal refah devletinin geçmişi 1600'lerde çıkartılan “yoksulluk yasaları"na kadar götürülse de (Özdemir, 2007) modern anlamıla refah devletinin kurumsal temelleri 1800'ler Almanya'sında Bismarck ile atılmıştır. Geçmişteki çeşitli yönetimlerin halkın daha iyi yaşam sürmesine yönelik bazı uygulamaları olsa da refah devleti sanayileşme çağının gereksinimlerine cevap olarak ortaya çıkmıştır. Zira yaşanan savaşlar ve ekonomik krizler sonucu gittikçe kötüye giden hayat şartları ve fabrikalarda devam eden yıpratıcı çalışma ortamları çalışanların hayatını olumsuz etkileyerek, iş gücü kaynaklarını azaltmaktaydı. Tam da bu yönüyle, Marksist iktisatçıların refah devletini, kapitalist firmaların üstlenmesi gereken bazı masrafların devlet tarafından karşılanarak kapitalist girişimlerin yüklerini hafifletmekle itham ettiklerini belirtmek gerekir (Rosanvallon, 2004).

Ayrıca, aynı dönemlerde özellikle Sovyetlerden yükselerek yayılmaya başlayan komünizm ve sosyalizm ideolojileri de Avrupa halklarını etkilemeye başlamıştı. Bu gelişmelere bir cevap olarak refah devleti politikaları geliştirilmiştir. Bu yüzden, refah devleti sistemi sosyalistler tarafından, sosyalist devlet için bir adım olarak görülür; ancak öte yandan, refah devletini 
sosyalizm tehlikesine karşı bir önlem olarak gören dönemin politikacıları için ise "sosyalizmin en etkili panzehiri" konumundadır (Wahl, 2015).

Tam da bu noktada refah devletinin temellerini atan Sosyal Liberalizm görüşüne de değinmek kıymetli olacaktır. 19. Ve 20. Yüzyıllarda Thomas Hill Green, Leonard Trelawny Hobhouse ve John Atkinson Hobson gibi isimlerle anılmakta olan Sosyal Liberalizm; hükümetin ekonomi üzerinde daha fazla rol oynaması konusundaki görüşleri ile klasik liberalizmden ayrılmaktadır (Weiler, 1972, s. 141). Bu liberalizm anlayışında toplumun bireye üstünlüğü temel alınmakta ve birey ancak toplum içerisinde bir değere sahip olabilmektedir (Örs, 1997). Bu fikri, insanların doğuştan doğal haklara sahip olduklarının aksine toplumun getirdiği askerlik, komşu hakkı gibi haklar ile sahip olunabildiğini savunan T. H. Green de taşımaktadır (Örs, 1997). Klasik liberalizmin laissez faire anlayışının modasının geçtiğine inanan Green'in takipçileri sosyalizmden farklı olarak bir sınıf bilinci uyandırmak yerine sosyal reform adına ahlakı seferber etmekteydiler (Sawer, 2003, ss. 12-13). Green, ortak çıkarları ve genel bir isteği bir toplumun sürekliliği için elzem görmekte ve 'ortak iyi' ideasını ortaya atmaktadır (Örs, 1997). Bu amaçla da meslektaşları ile birlikte dönemlerinin halk eğitimi için; devlet müdahalesinin özgürlüğü daha da arttırdığı fikrinin savunulduğu ve aktif bir vatandaş olma ve ortak iyiyi devam ettirme görevlerinin ele alındığı ders kitapları hazırlamışlardır (Sawer, 2003, s. 22). Ortak iyi fikrinden etkilenen L. T. Hobhouse da bir hakkın toplumun iyiliğinden başka bir şey olmadığını ve herhangi bir hakkın herhangi bir formunun iyi bir sosyal amaca hizmet etmediğinde kaldırılması gerektiğine dikkat çekmekte; bireyler için gösterilen her hassasiyetin genel refah adına yapıldığının unutulmaması gerektiğini vurgulamaktadır (Hobhouse, 1893, s. 90). Liberal teori için temel olan haklar ve görevlerin; birey ve toplum ilişkisinde her şey olduğunu, bunların ortak iyi tarafından tanımlandığını (Hobhouse, 1919, s. 126) ve bu ortak iyinin toplumun her bireyini içerdiğini belirtir (Hobhouse, 1919, s. 142). Green' in görüşleri ile örtüşen, her özgürlüğün karşılıklı olarak bir kontrol eylemine dayandığ 1 anlayışını benimsemektedir (Hobhouse, 1919, s. 147). Hak ve görev konusunda ele alınan görüşler teoride olumlu gözükse de pratikteki karşılıklarının sınırı bilinememektedir.

Sosyal liberalizmin bir başka savunucusu olan J. A. Hobson da kapitalizmin mevcut problemlerinin çözümü ve eşit ekonomik haklar için daha fazla devlet müdahalesinin gerektiğine inanmakta (Townshend, 1990, s. 87), makinalaşmanın maddi ve manevi hastalıkların sebebi olduğunu ve modern endüstri toplumlarının sağlığını bozduğunu iddia etmektedir (Hobson, 1912, s. 402). Hobson; uzun süren iş saatleri, tehlikeli ve sağliksız iş şartları, kadın ve çocukların işe alımlarındaki artış ve büyükşehir hayatının yaygınlaşması gibi problemlerin saymakta ve serbest ticaretin bu sorunlara çözüm olmayacağını dile getirmektedir (Hobson, 1912, s. 405). Hobson'1n ortaya koyduğu bu sorunlara bir çözüm olması beklenen refah devleti uygulamalarının genel itibariyle Avrupa devletleri ile başlatılmasının en temel nedeni toplumların sağlığını bozan sanayileşmenin getirdiği bir olgu olmasıdır (Durdu, 2009). Bu sebeple, henüz sanayileşmemiş ya da Avrupa'ya kıyasla daha geç bir vakitte sanayileşmiş ülkelerin hala geleneksel yapılarını koruyarak bu yapıya daha az ihtiyaç duyduğunu görmekteyiz. Tam bir kronolojik sıra ile hangi devletin ne zaman refah 
devleti haline geldiğinin belirlenmesi kolay değildir, çünkü her bir devlet farklı uygulamaları farklı senelerde yürürlüğe koymuştur. Örneğin, emeklilik sistemini bir ülke daha önce benimsemişken diğer devlet iş kazaları ile ilgili sigorta sistemini uygulamıştır. Ancak bu farkl1lıklara rağmen, bütün refah devletlerinin ortak özelliğinin piyasa sisteminin sebep olduğu refah düzeyindeki farklılıkları devlet müdahalesi ile giderme gayreti olduğu öne sürülebilir (Toprak, 2015). Zira her birinde temel ihtiyaçların belirlenmesi ve devlet müdahalesi sağlanarak insanların yaşamlarını belli bir standartta sürdürmeleri amaçlanmıştır (Alp, 2008; Serdar, 2014).

Her ne kadar refah devletinin temel vaadi her bir vatandaşın olabildiğince eşit ve ekonomik açıdan rahat bir hayat yaşaması olsa da farklı devlet yapıları ve toplumların kültürlerine göre bu vaatler ve uygulanışları değişkendir. Refah devleti üzerine literatürde gün geçtikçe farklı sinıflandırmalar ve modeller oluşturulmakta ve değerlendirilmeler yapılmaktadır. Bu çalışmada farklı refah devleti modellerine odaklanmaktan ziyade, refah devletlerinin temel özellikleri inceleneceği için bütün sınıflandırmaların ele alınması yerine en çok atıf yapılan Esping-Andersen sınıflandırması esas alınacaktır. Esping-Andersen (1990) refah devletini üç modelde toplamaktadır: (i) Liberal, (ii) Muhafazakar, ve (iii) Sosyal Demokrat. EspingAndersen ülkeleri bu modellere dekomüdifikasyon seviyelerini dikkate alarak yerleştirmektedir. Dekomodifikasyon, "hem sunumun ölçüsünü (yararlanan nüfusun payı, yararların düzeyi ve kapsanan ihtiyaçların yelpazesi) hem de refah sunumunun gerçekleştiği yollarını (yararlanmanın koşulları) içeren karmaşık bir kıstas olarak belirtilebilecek bir kavramdır" (Toprak, 2015, s. 157). Dekomodifikasyon seviyeleri üzerinden tanımlanan bu üç modelde, en az dekomodifikasyonun olduğu ülkeler liberal olarak değerlendirilirken, sosyal demokrat refah devletleri en fazla dekomodifikasyona sahip olan ülkeleri oluşturmaktadır. Genel özellik olarak, bütün refah devletleri modellerinin merkezi bir otorite olarak değişen ölçülerde piyasaya müdahale ederek, vatandaşların hayat standartlarını yükseltmeyi hedeflediğini iddia edebiliriz. Bunu gerçekleştirmek için en önemli kaynağı vatandaşlarından topladığ1 vergiler olmaktadır. Bu vesile ile bir yandan kapitalizmin yıkıcı etkilerinden vatandaşlarını korurken, bir yandan da sosyalizm gibi ideolojilerin cazibesine karşı kapitalizmi korumuş olmaktadır.

\section{Sosyal Refah Devletinin Temel Özellikleri ve Eleştirisi}

Yukarıda tarihi arka planından ve Esping-Andersen sınıflandırmasına göre yapılmış günümüzdeki modellerinden bahsettiğimiz refah devletinin (i) Müdahaleci, (ii) Düzenleyici ve (iii) Gelirin Yeniden Dağıtıcısı olmak üzere üç temel özelliği vardır (Özdemir, 2007). Müdahaleci olma özelliğinden dolayı, bütün süreci piyasa kontrolüne birakmak yerine, gerekli gördüğü durumlarda sorunları çözmek için müdahale etmektedir. Düzenleyici olması sebebiyle, vatandaşların hayat standartlarının temel ihtiyaçların karşılanamayacağı bir seviyeye düşmemesi için asgari ücret, sağlık sigortası gibi düzenlemeleri yapmaktadır. Son olarak, vatandaşlardan topladığı vergileri veya diğer gelir kalemlerini diğer vatandaşların ihtiyaçlarını gidermek üzere sosyal hizmet veya doğrudan para transferi şeklinde gelirleri yeniden dağıtarak gelir seviyeleri arasındaki farkları azaltmayı hedeflemektedir. Bu üç temel 
özellik, beraberinde refah devletinin güçlü bir merkezi kontrolü elinde tutmasını da sağlamaktadır. Özel sektörün güçlü olduğu neoliberal toplumlarda bireylerin refahları piyasa şartları tarafından belirlenirken, piyasa sisteminin doğuracağı refah dağılımındaki eşitsizlikleri gidermek için yeniden dağıtım mekanizması aracılığı ile müdahale eden refah devletlerinde ulus-devlet güçlü bir pozisyonda olmaktadır. Çıkış amaçlarından biri her ne kadar piyasayı kısıtlayarak devlet kontrolünde tutmak olsa da refah devleti özellikle küreselleşme ile birlikte, özellikle 1980'ler sonrasındaki neoliberal politikalar sebebiyle spektrumun sosyal demokrat kısmından liberal tarafına doğru kaymaya başlamıştır (İ. Gümüş, 2018).

Herbert Marcuse (2002), refah devletini, tüm rasyonelliğine karşın bir özgürsüzlük devleti olarak değerlendirmektedir. Bu sistem ile toplumun bir parçası olan siyasal güçlerin engellendiğini belirterek, refah devletini, örgütlenmiş kapitalizmle sosyalizm arası, kölelikle özgürlük arası, totaliterlikle saadet arası bir yapı olarak tasvir etmektedir (Marcuse, 2002). Diğer bir deyişle, yeniden dağıtım mekanizması sayesinde piyasa haricinde araçlarla halkın refahını garanti altına almaya çalışan ulus-devlet, kimlerin bu refahtan pay almayı hak ettiğini belirleyecek gücü de elinde tuttuğu için halkı kontrol etme gücüne de sahip olur. Bunu yaparken, yeniden dağıtım mekanizmasının bir parçası olan ücretsiz eğitim gibi imkanlar aracılığıyla belli bir ideolojinin gençlere aktarılmasını sağlarken, yetişkinler için ise yeniden dağıtımdan pay alabilmek için "makbul vatandaş" olma şartı getirmektedir. Örneğin, bir ulusdevlet, refah dağıtımını yaparken bireysel olarak belli vatandaşları ötekileştirebilir. Bunu aynı zamanda bölgesel bazda yaparak, bir ulus-devletin sınırları içerisindeki belli bölgelere ihtiyaç duyulan yardımların sistematik olarak sağlanmaması neticesinde insanları belli davranış kalıplarına ve itaat etmeye yönlendirebilir.

Ulus-devlet yapısının bir türü olan refah devletinin, devletin ihtiyaç duyduğu vatandaşı sağlayacak kurumlara sahip olması gerekmektedir. Bu kurumlar sayesinde neyi nasıl yapması gerektiğini bilen, devletiyle bağları güçlü, işini kaybettiğinde yine devletten isteyerek devlete minnet duyması gereken ideal vatandaşlar yetişecektir. Bu kurumlardan en önemlisi eğitim kurumudur. Refah devleti, sağladığı refahın sürdürülebilirliğini sağlamak ve ideolojik olarak refah devletini içselleştirmiş vatandaşları yetiştirebilmek için eğitimi kullanabilir ve bunu da ücretsiz yaparak her vatandaşa ulaşabilir. Bunu yaparken sorgulamayı öğrenen fakat sorgulayışı devletin istediği şekilde olacak bireyler yetiştirme imkanına sahiptir.

Bunun yanı sıra, bu merkezi eğitim kurumları kapitalist üretim sistemi içerisinde uyumlu bir şekilde çalışacak, yani 'disiplinli' ve 'verimli' iş görebilecek işçiler yetiştirme imkanı sağlamaktadır. Bu refah devletleri için önemlidir çünkü ister sanayi ister hizmet üretimine dayalı ekonomiler olsun, refah devletinin sunduğu imkanların devamını sağlayacak üretimin yapılabilmesi için ihtiyaç duyulan iş gücü kapasitesini karşılayabilmenin yolu eğitimden geçmektedir.

Eğitim sürecini merkezileştiren refah devletleri, bunun yanı sıra, toplanılan vergiler sayesinde vatandaşların ihtiyaç duyduğu temel ihtiyaçları da merkezi olarak sağlamaktadır. Bunun 
neticesinde sorumluluk ve yardımlaşma geleneksel toplumlardaki gibi aile veya yaşanılan bölgedeki topluluklar sayesinde değil devlet eliyle sağlanmaktadır. Ancak bunun için vatandaşın vergi verme sorumluluğunu yerine getirmesi gerekir ki devlet de söz verdiği hizmetleri faal hale getirebilsin. Modern çağda bireyselleşmenin birçok farklı saikleri mevcut olmakla birlikte bunda refah devletinin merkezileşme çabasının etkisi de yadsınmamalıdır.

Refah devleti her ne kadar bir toplumsallaşma örneği olarak görülse de vatandaşların ihtiyaçlarının toplumsal bağlar sayesinde sivil toplum üzerinden yerine getirilebilirken devletin bu işleri üstlenmesi bireyselleşmenin önünü açmıştır (Kosotieti, 1987). Bu değişim artık günümüzde olması gereken olarak algılanmakta ve geleneksel dayanışmaya dayalı çözümler garip karşılanabilmektedir. Bu bireyselleşme aynı zamanda bireylere sosyal bir özgürlük de sunduğu için cazip gözükmekte ve geleneksel yöntem olarak yardımlaşma bir minnet ve karşılığında sosyal bir yük oluşturabileceği düşüncesi ile olabildiğince uzak durulacak bir seçenek olarak görülmektedir. Bir başka ifadeyle, yardımlaşma birbirini tanımayı ve bu da birbirinin hayatında gittikçe söz sahibi olmayı getireceğinden bireyler bu hakkı bir otorite olarak sadece devlette görmeyi tercih edebilmektedir (Wahl, 2015).

$\mathrm{Bu}$ şekilde güçlü bir merkezi devlet üzerinden yeniden dağıtımın yapılması ve sağlık gibi temel ihtiyaçların sivil toplum yerine devlet kurumları tarafından sağlanması toplumsal dayanışmayı ve toplumu oluşturan bireylerin birbirlerine olan ihtiyaçlarını azaltmaktadır. Bunun yerine, bireysellik artmakta, insanlar piyasa sisteminin sağladığ aracılığı ile ihtiyaçlarını karşılamakta ve gerektiği durumda devlete sığınmaktadırlar. Bu şekilde bireyselleşen toplumlarda aile yapısı giderek küçülmekte, çekirdek aile olarak tanımlanan anne-baba ve çocuklar arasındaki ilişki dahi çoğu ülkede çocukların kendi kararlarını uygulama yaşı olarak kabul edilen 18 yaşına kadar devam etmektedir. Toplumda bir vatandaş ve bir birey olarak bulunan insanlar için en önemli dayanak devlet olmaktadır. Bu dayanağa sahip olabilmek için de devletin talep ettiği iyi bir vatandaş olma şartını yerine getirmek gereklidir. Piyasa sisteminin daha liberal olarak işlediği Amerika gibi toplumlarda iyi bir kredi skoruna sahip olmak, yani iyi ve güvenilir bir müşteri olmak ne kadar önemliyse, refah devletlerinin sunduğu imkanlardan faydalanabilmek için de vatandaş skorunun yüksek olması gereklidir. Her ne kadar iyi vatandaş olma şu ana kadar nicel olarak tespit edilen bir kavram olmasa da Çin'in teknolojiyi kullanarak oluşturmaya başladığı vatandaş puanları (Topçu, 2020) yakın gelecekte "iyi vatandaş" olmanın çok daha detaylı şekilde tespit edilebileceğine işaret etmektedir.

Burada iyi vatandaş ile kastedilen, devletin vatandaşından beklediği görevleri yerine getiren bireyler olmak demektir. Sosyal Liberalizmin öncülerinden olan L. Hill Hobhouse'ın ifadesi ile haklar ve görevler, uyum içindeki bir hayat olarak tanımlanan sosyal refahın şartlarındandır (Hobhouse, 1922, s. 35). Bu görevlerin başında kanunlara uymak gelmektedir çünkü devletin otoritesi ve toplumun düzeni bu sayede sağlanmaktadır. Bunun yanı sıra üretici bir faktör olarak toplumun refahına katkı sağlamak da çok önemlidir. Diğer bir ifadeyle, bu sistem içerisinde yer alan bireyin ya çalışması ya da çalışamaz durumda olması beklenir. Çalışmaya imkanı olmayan bireyler ise "devletin sırtında bir yük" olarak 
görülmektedir. Üçüncü bir ihtimal olan çalışmayı istememe, bir başka ifadeyle -isteğe bağlı olarak- üretici bir faktör olarak bu sistemde bulunmama gibi bir seçenek sunulmamaktadır (Wahl, 2015).

Her ne kadar sağlık sorunları sebebiyle refah devletine üretici bir faktör olarak katkıda bulunamayan kişiler devletin desteğinden mahrum olmasa da alınan çeşitli önlemler sayesinde yeni doğacak vatandaşların refah devletine gerekli katkıyı yapabilecek kapasitede olması için gayret gösterilmektedir. Bu gayretler gelecekte, hamilelik sırasında -olasılık olaraktespit edilebilen Down sendromu gibi hastalıkların ortaya çıkma ihtimalinin yüksek olduğu durumlarda ortaya çıkması muhtemel tedavi ve bakım masraflarını ortadan kaldırmak ve ailelerin üretkenliklerini arttırmak için hamileliğin mecburi olarak sonlandırılması gibi politika uygulamalarına yakın gelecekte başlayabilirler (Stone, 1989). Henüz resmi olarak vatandaş olmamış bir cenin için bu "sonlandırma" kararı daha rahat verilebilirken, yaşlılık veya yatağa bağlı hastalıklar gibi üretici kapasitenin olmadığı durumlarda ötanazi uygulanmasına izin verilmesi veya teşvik edilmesi sıradaki adım olabilir.

\section{3. İslam Ekonomisi Açısından Refah Devletinin Bir Analizi}

İslam ekonomisine dair yapılan kavramsal çalışmaların oluşmaya başladığı 1920'lerden itibaren, yaşadıkları dünyaya bir teklifte bulunmak amacıyla yola çıkan araştırmacıların İslam ekonomisini tanımlarken o yılların popüler iki ideolojisi olan sosyalizm ve kapitalizm üzerinden bir tanımlama girişiminde bulunduklarını görürüz (Șiddī $q \overline{1}, 1981)$. İslam ekonomisi çalışmalarının yoğunlaştığı 1970 ve 1980'li yılları incelediğimizde ise İslam ekonomisinin sosyalizm ve kapitalizmle benzeşen ve ayrışan yönleri üzerinden bir kimlik inşası gerçekleştirme çabasının devam ettirildiğini görürüz (Bkz: Arif, 1985; Choudhury, 1982; Hasan, 1983; Naqvi, 1978; Pryor, 1985). Diğer yandan içinde yaşanılan şartlara ve İslam dünyasının problemlerine karşı Naqvi (1978) ve Chapra (1979) gibi alanın kurucu isimleri tarafından -ahiretin ihmal edilmemesi koşuluyla- ideal bir modern çözüm ve İslam ekonomisine yol gösterici olarak refah devleti modeli önerilmiştir.

Burada önemli hususlardan biri, bir İslam devleti olarak kurulan Pakistan'ın iktisadi yapısını inşa etme misyonunu üstlenen Naqvi gibi isimlerin önünde pratik bir soru olarak duran "İslam Devletinin ekonomik sistemi nasıl olmalıdır?" sorusuna hızlı bir şekilde cevap bulma ihtiyacıdır. İslam ekonomisinin teorik altyapısını kurmaya çalışan kurucu isimlerin bu pratik ve acil kaygıdan dolayı halihazırda denenmiş ve uygulanıyor olan sistemler üzerinden analize gitmesi ve kendilerine en yakın gördükleri seçeneği uyarlamaya çalışmaları makul görülebilir. Ancak bir adım geriye giderek İslam ekonomisini bir disiplin olarak kuran isimlerin tartışmadan kabul ettiği ulus-devletin İslamileştirilerek modern bir İslam devleti kurmanın imkanı ve ulus-devletin kurumlarının İslam ahlakı ile ne derece uyumlu olabileceğine bakıldığında (Hallaq, 2012), kurucu isimlerin tartışmadan aldığı bazı kavramların ve teorik zeminin aslında eleştiriye açık olduğu anlaşılmaktadır. Bu bölümde amacımız, bazı İslam ekonomisi araştırmacıları tarafından İslami prensiplerin uygulanması açısından başarılı ülkeler olarak görülen ve İslamilik indekslerinde ilk sıralarda gelen Hollanda ve İsveç gibi 
refah devleti örneklerini (Askari \& Mohammadkhan, 2017) İslam ekonomisi açısından eleştirel bir analize tabi tutmaktır. Her ne kadar bu çalışmada amaç devlet teorisi üzerine bir analiz olmasa da refah devleti eleştirisi yapabilmek için devlet olarak tanımlanan yapının ne olduğundan veya olmadığından ve bu yapının Müslüman toplumlarda nasıl bir siyasi otorite aracılığıyla temsil edildiğinden kısa da olsa bahsedilmelidir.

\subsection{Müslüman Toplumlarda Siyasi Otoritenin Rolü}

Modern öncesi dönemdeki Müslüman toplumlarda var olan siyasi otoritelere baktığımızda, bu otoriteyi temsil eden kişi ve kurumların genel olarak hüküm sürülen topraklarda yaşayan Müslüman ve Müslüman olmayan kişiler arasında adaletin uygulanması ve dışarıdan gelen tehlikelere karşı güvenliğin sağlanması ile sorumlu olduklarını görürüz. Bu sorumluluklara ek olarak, bugün çoğunluğu ulus-devletlerin sorumluluğu olarak görülen ve devlet kurumları aracılığıyla sağlanan eğitim, sağlık ve yardım faaliyetleri gibi çalışmalar modern öncesi Müslüman toplumlarda vakıflar eliyle yerine getirilmiştir (Çizakça, 2006). Bu vakıfların bazıları yönetici otoritenin kendi servetlerinden bağışladıkları mülkler sayesinde kurulan vakıflarken bazıları ise varlıklı Müslümanlar tarafından oluşturulan vakıflardır (Atçıl, 2018). Müslüman toplumlarda kurulan bu vakıfların sunduğu eğitim, sağlık ve yardım hizmetleri, göreceli olarak da olsa- siyasi otoriteden bağımsız bir sivil alanın oluşması ve bu sosyal imkanlardan faydalanan kişilerin siyasi otoriteye tam bağımlı olmadan yaşamlarını sürdürmelerini sağlamıştır (Atçıl, 2018). Vakıfların yanı sıra, modern öncesi dönemde toplumu oluşturan üyelerin birbirleri ile dayanışma içerisinde olması, dolayısıyla ihtiyaçların siyasi bir otorite veya merkezi bir güç tarafından giderilmesi yerine yerel dayanışmalar neticesinde çözüme kavuşturulması (Fotopoulos, 1994; Polanyi, 2001), sivil toplumun siyasi otoriteden bağımsız bir alan oluşturmasına olanak tanımıştır.

Siyasi otoriteden -modern devlet yapısına mukayese ile- göreceli olarak bağımsız bir alanda faaliyetlerini sürdüren vakıfların ve kurum yerine insan eliyle sağlanan dayanışma aracılığıyla yaşamlarını sürdüren insanların özellikle eğitim ve adalet konusunda sivil bir alan oluşturmayı başardıkları iddia edilebilir. Bireylerin özgürlüğü ve güçlenmesi ile yakından ilişkili olan eğitim sistemi modern dönemde merkezi olarak tasarlanmış ve devletin ideolojisini yaymak için kullanılan önemli araçlardan biridir. Günümüzden farklı olarak, modern öncesi Müslüman toplumlarda siyasi otorite tarafından belirlenen merkezi bir eğitim sisteminin olmaması ve eğitimin içeriğinin dersi veren alimler tarafından -tarihi tecrübe içerisinde şekillenen metinlerden de istifade edilerek- belirlenmesi ve şekillenmesi, alim adaylarının süregelen geleneğin bir parçası olarak yetişmesini ve merkezi bir otoriteden alınan kurumsal diploma yerine tedrisatından geçtikleri alimlerden icazet alarak yetkinliklerini ispatlamalarını sağlamıştır (Fazlığlu, 2008). Diğer yandan, eğitim kurumlarının ayakta kalması ve ilim geleneğini sürdürmesi için gereken maddi desteğin bu amaca matuf vakıflar tarafından sağlanması da ekonomik bağımlılı̆̆ı azaltmıştır (Atçıl, 2018). Bu yetişme sürecinden geçen alimler, adalet sisteminin temelini oluşturan Şeriat konusunda söz söyleyecek yetkinliğe ulaşarak toplumsal yaşamın İslam'ın temel esaslarına ve öngördüğü adalete uygun bir şekilde sürdürülmesinde etkili olmaya başlamaktadır. Bahsi geçen eğitim 
süreciyle yetişen müftülerin verdiği fetvaların veya kadıların verdiği hükümlerin temel dayanakları tarihi süreç içerisinde yerleşmiş olan mezhep doktrini tarafından -genel hatlarıyla- siyasi otoritelerden bağımsız olarak belirlendiği için (Hallaq, 2012), adalet mekanizmasının sadece siyasi otoritenin kontrolünde olmadığı iddia edilebilir. Bu durum siyasi otoritenin eğitim ve adalet sistemlerine müdahale etmek ve hatta şekillendirmek istemediği anlamına gelmez. Ancak dinin toplumsal yapıyı belirlemedeki önemli rolü düşünülünce (Thornton \& Ocasio, 2008), toplumun içerisinden yetişmiş olan alimlerin, siyasi otoritenin karşısında önemli bir güç olarak var olduğu iddia edilebilir.

Merkezi şekilde örgütlenmiş ve özünde ilerlemeci bir yapıya sahip modern devletin (Hallaq, 2012) bir çeşidi olan refah devleti, modern öncesi Müslüman toplumlardan daha farklı bir yapılanmaya sahiptir, dolayısıyla yukarıda ifade edilen toplumsal ilişki ve kurumlardan da farklı bir yapı sunmaktadır. Bu farklılığın temelinde, refah devletlerinde yeniden dağıtım mekanizmasının işletilmesi ve eğitim başta olmak üzere birçok konuda karar verici ve uygulayıcı kurumların merkezi bir şekilde belirlenmesi ve denetlenmesi sebebiyle sivil toplumun gücünün ve toplumu oluşturan bireylerin arasındaki dayanışmanın azalması yatmaktadır. Toplumu oluşturan üyeler arasındaki dayanışma aracılığıyla sağlanan birçok imkan yerini refah devleti kurumlarının ücretsiz veya cüzi ücretlerle sağladığı hizmetlere birakmaktadır.

İkinci bölümde zikrettiğimiz Esping-Andersen sınıflandırmasına göre "Sosyal Demokrat" kategorisinde olan refah devletlerinde bu hizmetlerin sağlanması devletin sorumluluğundayken, "Liberal" ülkelere doğru ilerledikçe piyasa sisteminin bu rolü üstlenmeye başladığını görmekteyiz. Diğer bir ifadeyle, ürün ve hizmetlerin vatandaşlara sağlanma görevi devlet ve piyasa arasında değişmektedir. Kamu ve özel sektör haricinde bulunan sivil toplumun bu hizmetleri bir dayanışma içerisinde sağlama oranı ise devletin sosyal demokrat-liberal olma aralığındaki konumuna göre ve devletin vatandaşların ihtiyaç duyduğu eğitim, sağlık ve maddi yardımlar gibi hizmetlere ayırdığı kaynakların miktarına göre değişmektedir. Bunun arka planında ise bireyselleşen toplumsal yapı ve ulus-devlet karşısında tikel bir varlık şeklinde "vatandaş" olarak yer almamız önemli bir rol oynamaktadır. Modern birey, sosyal devlet modelini benimseyen refah devletlerinde devletine bağlı ve onun sayesinde varlığını sürdüren "iyi vatandaş” olarak bulunurken, refah devletinin daha liberal formlarında piyasada bir müşteri (tüketici) ve işçi (üretici) olarak yer almaktadır. Modern kapitalist refah devleti yapısında tek başına bir vatandaş ve müşteri olarak yer bulan "birey"in, bu ilişki ve kurumlar yapısı içerisinde ne kadar özgürleşebileceği ve güç sahibi olabileceği İslam iktisadı açısından önem arz etmektedir. Bu bağlamda, refah devletlerinin İslam ekonomisi açısından eleştirisini yaparken odaklanmamız gereken iki kavram özgürlük (emancipation) ve güçlendirme (empowerment) olacaktır (Asutay, 2017, 2018).

\subsection{Refah Devletlerinin Özgürlük ve Güçlendirme Kavramları Bağlamında Bir Eleștirisi}

İslam’a göre insanların yaratılış amacı Allah'a kulluk etmektir. Bütün hayatını Allah'a kul olarak geçirmenin ön şartı ise kişinin başkalarına kul olmaya yol açacak her türlü bağdan 
kurtulması; böylece özgür iradesi ve sahip olduğu güç ile Allah'a ibadet edebilmesidir. Burada ibadetten kasıt sadece namaz ve oruç gibi temel dini vecibelerle sınırlı olmayıp kişinin geçimini sağlamak için yaptığı uğraşlar, helal rızık kazanmak ve doğru şekilde ibadet etmek için ihtiyaç duyduğu ilmi talep etmek gibi eylemleri de içermektedir.

Her ne kadar makāsıdü'ş-şerîa (Şeriatın gayeleri) temel alınarak belirlenen göstergelere göre hazırlanan listelerde Hollanda ve İsveç gibi refah devletleri İslami olmak bakımından ilk siralarda yer alsa da (Askari \& Mohammadkhan, 2017) bu göstergeler elde mevcut olan makro veriler kullanılarak hazırlanmış olmaları ve göstergelerin gerçekte ifade ettiği anlamların eleştirel bir analize tabi tutulmamış olması sebebiyle yanıltıcıdır (Asutay \& Yılmaz, 2018). Nitekim, refah devletlerinin uygulamaların bireylere Allah'a ibadet etme noktasında sağladığı özgürlük ve güçlendirme üzerinden bir eleştiriye tabi tuttuğumuzda bu çelişki daha açık olmaktadır.

Modern öncesi dönemde içinde bulundukları durumlara dayanışma içinde çözüm bulan Müslüman topluluklar, modern devlete kıyasla siyasi otoritenin kontrolünü daha az hissetmekteydi. Her ne kadar coğrafya ve zaman diliminin farklılaşmasına göre bu durum değişiklik gösterebilse de modern devletin vatandaşlık numarası sayesinde herkesi takip edebildiği ve herhangi bir ceza vermek istediğinde bunu ulus-devlet sinırları dahilinde kolaylıkla uygulayabildiği düşünüldüğünde modern öncesi dönemde bulunan göreceli özgürlük daha iyi anlaşılabilir. Modern refah devletinin özgürlük sinırlamalarının karşıllı̆ında, iyi bir vatandaş olunduğu, yani ulus-devletin koyduğu hukuk kurallarına anlamsız veya adaletsiz olsalar dahi- uyulduğu takdirde, devletin sağladığı koruma ile büyük ölçüde -en azından maddi olan- belirsizlikler, zorluklar ve tehlikeler bertaraf edilebilmektedir. Diğer bir ifadeyle, refah devletinin sunduğu refahtan istifade edebilmek için özgürlüklerin göreceli olarak terk edilmesi gerekir (Marcuse, 2002). Burada Allah'a “iyi bir kul” olmakla, ulus-devletin "iyi bir vatandaşı" olma ikiliği dikkat çekicidir. Refah devletine isyan etmek ve kurallarına uymamak ülke sınırları dahilinde -ve hatta ötesinde- devletin "merhametinden ve kereminden" mahrum kalmaya yol açabilir.

Vatandaşların arzu edilen hale gelmesinde en büyük rol devletin ideolojisini vatandaşlara küçük yaştan itibaren empoze eden eğitim kurumlarınındır (Althusser, 2014). Bu nedenle, özgürce verildiği düşünülen birçok karar aslında bütün vatandaşların geçtiği tedrisat neticesinde küçük yaştan itibaren aktarılan devlet ideolojisi üzerine inşa edilerek verilmektedir. Bazı refah devletlerinde ise okula gitmek zorunlu olmasa da eğitim diplomalarının verilmesi merkezden kontrol edildiği için resmi olarak "eğitimli" kabul edilmek isteyen vatandaşların bilmesi ve bildiğini ispat etmesi gereken bilgilerin devlet tarafından belirlenmektedir. Bu sebeple, refah devletinde yaşamak sadece refah içinde yaşamak demek değil, refah devletinin ideolojisini kabul ederken ayn zamanda merkezi otoritenin vatandaşa yönelik taleplerini içselleştiren ve uygulayan bir vatandaş olmak demektir. En azından "iyi bir vatandaş" böyle olmalıdır. Şüphesiz ki pratikte bu durumun hedeflenen ideale ne kadar yakınlaştığı tartışmalıdır. İdeale yakınlaşmayı engelleyen en önemli sebepler, merkezi bir şekillendirmeye karşı koymaya çalışan bireysel tutumlar ve 
eğitim kurumlarının merkezin hedeflediği aktarımı -yetersiz personel ve maddi imkansızlıklar gibi sebeplerle- yeteri kadar yapamamasıdır.

Eğitim sistemi sadece refah devletinin ideolojisini içselleştiren vatandaş yetiştirmekle kalmamakta aynı zamanda bu refahın devam etmesini sağlayacak iş gücünü oluşturmak için kapitalist sistem içerisinde işçi, girişimci veya işveren olacak bireylere de gerekli olan beşeri, kültürel ve sosyal sermayeyi kazandırmayı amaçlamaktadır. Bu yüzden eğitim kurumları, kurum içi ilişkiler ve eğitim müfredatının içeriği vatandaşların Allah’a iyi bir kul olmasını değil, kapitalist sistem içerisinde yetkin birer girdi olarak yetişmesini hedeflemektedir (Rosen, 1983; Schultz, 1961; Wolf \& Wright, 2014). Bu durum nüfusunun çoğunluğu Müslüman olan ve olmayan refah devletleri arasında bir fark oluşturmayacaktır. Çünkü bu yapının devamı için gerekli olan ve bütün vatandaşları kapsayacak eğitim bunu gerektirmektedir.

Refah devletini -bazı eksikleri ile beraber- ideal bir İslam ekonomisi örneği olarak gören Naqvi'nin (1978), Pakistan'ın kalkınması için çözüm olarak önerilerinden biri olan ülke genelinde eğitim sisteminin iyileştirilmesi fikri de bu yüzden aynı kapitalist sosyal yapıyı üretmeye devam etmenin ötesine geçemeyecektir. Çünkü okulların -Batılı anlamdakalkınmayı üretmek için gereken bilgi ve becerileri sağlarken aynı zamanda ulus-devletin bir gereği olarak bu öğrencileri birer vatandaş ve kapitalist sistem içerisinde birer girdiye dönüştürür. Sonuç olarak, refah devleti, bilinçli olarak veya aldığı eğitim neticesinde içselleştirdiği ideoloji sebebiyle farkında dahi olmadan, Allah'a kul olma imkanı sağlayacak özgürlük ve içinde bulunduğu yerel topluluk sayesinde varlığını sürdürecek birliktelik yerine refah devletine bağlı ve devletin sunduğu imkan ve hizmetlerle varlığını sürdüren bireyler üretmeyi hedeflemektedir. Bu noktadaki sorun, Allah'a kul olmak ile vatandaş olmak arasında çıkacak herhangi bir çatışmada bireylerin özgürce seçim yapmalarına engel olacak ölçüde kuşatıcı olan ulus-devlet otoritesinin varlığıdır. Bu noktada yaşanabilecek çatışmaların farkına varabilmek için refah devletlerinin temelini oluşturan ulus-devlet yapısının ontolojik bir kritiğinin yapılması gereklidir. ${ }^{1}$

Refah devletinin sunduğu imkanlardan yararlanmak için ödün verilmesi gereken özgürlüğün yanı sıra, refah devletinin sunduğu imkanlar sayesinde varlığını sürdürebilen vatandaşlar siyasi otoriteden bağımsız sivil bir güç oluşturma çabasına da girme ihtiyacı duymamaktadır. Burada vurgulanması gereken nokta, sadece sivil bir dayanışmanın veya hizmetin oluşturulmasının ötesinde bu dayanışmanın finansal kaynaklarının ve ideolojik arka planının da siyasi otorite tarafından sağlanıyor olmasıdır. Güçlü bir refah devleti tarafından sunulan ücretsiz sağlık hizmeti, işsizlik desteği, çocuk yardımı ve emeklilik maaşı gibi destekler sayesinde iyi bir vatandaş hayatı boyunca endişelenmeye gerek duymayacaktır. Kapitalist sistem içerisinde bir işçi olarak yer alan ve kariyerinde daha iyi bir yere ulaşmak için beşeri sermayesini artırması beklenen vatandaşların duyduğu bu güven duygusu dayanışma içerisinde olduğu bir topluluk veya kendi başına bir mükellef olarak sorumluluklarını yerine getirebilme becerisine sahip olmaktan ziyade, ulus-devlet yapısı içerisinde iyi bir vatandaş

\footnotetext{
${ }^{1}$ Bu konu üzerine detaylı bir çalışma için bkz: Hallaq (2012)
} 
olarak bulunması sayesinde gelmektedir. Diğer bir ifadeyle, bir vatandaş, bireysel olarak veya sivil bir dayanışma sayesinde değil, devletin onu iyi bir vatandaş olarak kabul etmesi sayesinde güçlüdür. Çünkü, refah devletinin yapısı vatandaşların refah devletine dayanmadan varlıklarını sürdürebilecekleri bireysel ve toplumsal düzeyde gerçekleşecek bir güçlenmenin önüne geçmektedir.

Ancak vatandaş, makbul vatandaş olma şartlarını yerine getiremediğinde hiçbir hakkı kalmayabilir ve yaşamını kendisine karşı sorumlu hisseden bir topluluğun parçası olarak sürdürme imkanı bulamayabilir. Bu da bireyleri daha fazla devlete bağlı olmaya mahkum eder. Bu farklılıklar, refah devletinin yeniden dağıtım mekanizmalarını ne ölçüde tekelinde tuttuğu ve misyonunu ne derece başarılı şekilde gerçekleştirebildiği ile yakından ilgilidir. Refah devleti, vatandaşların refahını garanti etmek için yeniden dağıtım mekanizmasını merkezi şekilde kontrol etmekte ve vatandaşlardan topladığı vergileri kendi uygun gördüğü yere istediği şekilde harcamaktadır. Böyle bir durumda hem sosyal destekler hem de yerel güvenlik gibi birçok sorumluluk, ödenen vergiler yoluyla devlete devredilmekte ve buna bağlı olarak toplumu oluşturan bireyler arasındaki sorumluluk bağı ortadan kalkarak yerini yetkili mercilere haber vermeye birakmaktadır.

Bunun da ötesinde, Müslüman toplumlarda sivil bir faaliyet olarak süregelen zekat veya sadaka gibi sivil yardım faaliyetler de yeniden dağıtım mekanizmasının bir parçası olarak "maddi yardım" ortak paydasında buluşturularak devlet eliyle merkezi olarak organize edilmeye başlamıştır (Ab Rahman vd., 2012; Hudayati \& Tohirin, 2010). Bu da bireyleri refah devleti tarafından "iyi vatandaş" olarak sayılmadıkları takdirde zekat ve sadaka gibi devlet eliyle dağıtılan toplumsal yardımlardan da mahrum bırakarak daha yalnız ve güçsüz bir hale getirmektedir.

Refah devletinin kurumsal yapısında olduğu gibi vatandaşların her çözümü devletten beklediği, sivil bir topluluk oluşturamadıkları ve siyasi otoriteden bağımsız güç sahibi olamadıkları siyasi oluşumlarda Allah'a kul olma ve ona ibadet etme ile iyi bir vatandaş olma arasında seçim yapmak zorunda kaldıklarında, vatandaşların dayatılan uygulamaları reddetmesi veya sivil itaatsizlik göstermeleri cesaret gerektirecektir (Moore, 1987). Bunun yanı sıra, vatandaşlar sivil itaatsizlik veya hukuki sınırlar içerisinde eylemde bulunsalar dahi, bu itirazlarını yine genelde modern devlet, özelde ise refah devletinin temel varsayımları ve prensipleri, yani aydınlanma sonrası metafizik anlayışa dayanan insan hakları ve benzeri söylemler üzerine inşa edebileceklerdir. İslam gibi ontolojik düzlemde refah devlet yapısı ile çatışan bir dinin normatif kuralları üzerine inşa edilecek itirazlar bu söylem içerisinde kendine yer bulamayacaktır (Hallaq, 2012).

\section{Sonuç}

Şeriatın gayeleri temel alınarak hazırlanan İslamilik indekslerine göre ilk sıralarda yer alan ülkelerin siyasi yapısını temsil eden refah devleti modeli, eskiden beri İslam iktisadı araştırmacıları tarafından -ahiret inancının hesaba katılmaması gibi- bazı eksikliklerine rağmen ideal bir model olarak görülmektedir. Ancak bu İslami modelin özgürleşme ve 
güçlendirme kavramları üzerinden bir eleştirisi yapıldığı takdirde, İslamilik indekslerinde refah devleti örneklerini üst sıralara taşıyan bazı özelliklerin İslam'ın ön gördüğü Allah'a kul olmayı hayatın merkezine yerleştiren Müslüman yerine, iyi bir vatandaş olmayı öncelemek zorunda kalan bireyler yetişmesinde anahtar rol oynadığ 1 dikkat çekmektedir. Bunun temelinde yatan sebep ise refah devletlerinin sunduğu refahtan istifade edebilmek için öncelikle devletin öngördüğü iyi vatandaş olmanın gerekliliğidir.

$\mathrm{Bu}$ çalışma bağlamında, bireylerin iyi vatandaşlar olmasını sağlayan iki temel noktaya değindik. İlki, refah devletlerinin yeniden dağıtım mekanizmasını merkezden kontrol ederek refahın kimlere ve nasıl ulaştırılacağını belirleyebilmesidir. Bu sayede, bir bireyin refahtan payını alabilmesi için refah devletinin iyi vatandaş tanımına uyması, yani devletin kanunlarına uyan ve kapitalist piyasa sistemine -herhangi bir engel olmadığı takdirdeüretken bir girdi olarak katılan bir birey olması gerekmektedir. İkincisi, refah devletinin ücretsiz olarak sunduğu eğitim imkanları, yani okul kurumu sayesinde bireylerin küçük yaştan itibaren iyi bir vatandaş olmak üzere yetiştirilmeleri ve iyi bir vatandaş olmanın gereklerini içselleştirmeleridir. Refahtan payını alabilmek için dışsal bir motivasyonla veya okul kurumu aracılığıyla içselleştirdiği dahili bir motivasyonla itaatkar bir vatandaş olmak, bireylerin özgürlüklerinden de -önemli ölçüde- vazgeçmesi anlamına gelmektedir.

Merkezi bir şekilde sunulan refah bireylerin özgürlüğünü önemli ölçüde ellerinden alırken, eğitim, sağlık ve maddi destek gibi birçok ihtiyacın devlet eliyle sunulması; sivil toplumun organize olarak siyasi otoriteden bağımsız bir güç oluşturmasını ve bireylerin devletin sunduğu imkanlardan bağımsız, özerk bir alan oluşturmalarının önüne geçmektedir. Bu sebeple, bireyler güçlerini iyi bir vatandaş olmaları neticesinde devletin sunduğu imkanlar sayesinde alırlar. Diğer bir ifadeyle, iyi bir vatandaş oldukları ölçüde güçlü olmaktadırlar. Bunun haricinde, devletten bağımsız olarak sivil bir güç alanının olması söz konusu değildir.

Özgürlük ve güç açısından yoksun bireyler haline gelen vatandaşlar, refah devleti içerisinde kalkışacakları herhangi bir eleştiriyi ve meydan okumayı ancak aydınlanmanın bir ürünü olan mevcut modern paradigma içerisinden seslendirebilirler. Bu sebeple, Allah'a kul olma amacıyla yapılacak bir hareket vatandaşlık tanımıyla uyumlu olduğu sürece makbul olacaktır.

Halbuki, İslam ekonomisinin tahayyül ettiği siyasi yönetimde mükelleflerin özgürlügünden mahrum ve güçsüz bir konumda bulunmaması esastır. Refah devleti açısından iyi olarak görülen hatta ihtiyaç duyulan ancak İslami bir düzen açısından münker olarak kabul edilen bir şeyle karşılaşıldığında çekinmeden menedebilecek mükellefler ancak böyle bir toplumda bulunabilir. Bunu sağlayabilmek için de İslami özellikleri haiz bir toplumsal yapıda inşa edilecek eğitim ve adalet kurumlarının, bu toplumda yaşayan mükellefleri merkezi bir güce bağımlı olmayacak imkanları sunması ve Allah'a ibadet edebilecek kullar olabilmek için gerekli bilgi, beceri ve güç ile donatacak kurumlar olması gerekir.

$\mathrm{Bu}$ makalenin temel amacı toplumsal refahı merkeze alarak yapılacak bir analiz açısından ideal olarak görülecek refah devleti modelinin özgürleşme ve güçlendirme gibi kavramlar açısından ele alındığında olumsuz taraflarının ortaya konulmasıdır. Böylece refah devleti, 
sunduğu imkanların ötesinde, vatandaşları mahrum bıraktı̆̆ı hususlarla ön plana çıkartılmaya çalışılmıştır. Daha ileri çalışmalarda farklı refah devletleri örnekleri üzerinden ampirik çalışmalar yapılarak burada getirilen eleştirilerin gündelik hayattaki sonuçları araştırılabilir. 


\section{Kaynakça}

Ab Rahman, A., Alias, M. H., \& Omar, S. M. N. S. (2012). Zakat institution in Malaysia: Problems and issues. Global Journal Al-Thaqafah.

Alp, Ö. (2008). Yeni Bir Refah Devleti Modeline İlişkin Temellendirme (Aristotelesçi Bir Yaklaşım: Yetenekler ve İşlevlilikler). İstanbul Üniversitesi.

Althusser, L. (2014). On the reproduction of capitalism: Ideology and ideological state apparatuses. Verso.

Arif, M. (1985). Toward a definition of Islamic economics: Some scientific considerations. Journal of King Abdulaziz University: Islamic Economics, 2(2).

Askari, H., \& Mohammadkhan, H. (2017). Islamicity indices: The seed for change. Springer.

Asutay, M. (2017). Emancipation and Empowerment: Re-Framing the Objective of Islamic Moral Economy. 29th Annual Meeting.

Asutay, M. (2018). Beyond Finance in Islamic Finance: Islamic Moral Economy for Emancipation and Empowerment. 30th Annual Meeting.

Asutay, M., \& Yilmaz, I. (2018). Re-embedding Maqasid al-Shari'ah in the essential methodology of Islamic economics. İçinde M. T. El-Mesawi (Ed.), Maqasid al-Shari'ah: Explorations and implications. Islamic Book Trust.

Atçll, A. (2018). Scholars and sultans in the early modern Ottoman Empire. New York: Cambridge University Press.

Briggs, A. (1961). The welfare state in historical perspective. European Journal of Sociology/Archives europeennes de sociologie, 2(2), 221-258.

Chapra, M. U. (1979). The Islamic welfare state and its role in the economy. Islamic Foundation.

Choudhury, M. A. (1982). Principles of Islamic economics. Islamic Studies, 21(2), 89-107.

Çizakça, M. (2006). Economic dimensions of foundations in the Ottoman era. Philanthropy in Turkey: Citizens, foundations and the pursuit of social justice, 28-42.

Durdu, Z. (2009). Modern devletin dönüşümünde bir ara dönem: Sosyal refah devleti. Muğla Üniversitesi Sosyal Bilimler Enstitüsü Dergisi, 22, 37-50.

Esping-Andersen, G. (1990). The three worlds of welfare capitalism. Princeton University Press.

Fazlıŏlu, Ş. (2008). Osmanlı Medrese Müfredatına Dair Çalışmalar: Nereden Nereye? Türkiye Araştırmaları Literatür Dergisi, 12, 593-610.

Fotopoulos, T. (1994). The Nation-State and the Market. Society and Nature, 2(2), 37.

Gümüş, A. T. (2010). Sosyal devlet anlayışının gelişimi ve dönüşümü. On İki Levha Yayıncılık.

Gümüş, İ. (2018). Tarihsel perspektifte Refah Devleti: Doğuş, Yükseliş ve Yeniden Yapılanma Süreci. Journal of Political Administrative and Local Studies, 1(1), 33-66. 
Hallaq, W. (2012). The Impossible State: Islam, Politics, and Modernity's Moral Predicament. Columbia University Press.

Hasan, Z. (1983). Theory of profit: The Islamic viewpoint. Journal of King Abdulaziz University: Islamic Economics, 1(1).

Hobhouse, L. T. (1893). The labour movement. Unwin.

Hobhouse, L. T. (1919). Liberalism. Williams \& Norgate. http://online.canadiana.ca/view/oocihm.65557

Hobhouse, L. T. (1922). The Elements of Social Justice. Holt and Company.

Hobson, J. A. (1912). The Evolution of Modern Capitalism: A Study of Machine Production. The Walter Scott Publishing.

Hudayati, A., \& Tohirin, A. (2010). Management of zakah: Centralised Vs decentralised approach. Abdul Ghafar Ismail Mohd Ezani Mat Hassan Norazman Ismail Shahida Shahimi, 352.

Illich, I. (2013). Okulsuz toplum (M. Özay, Çev.; 8. bs). Şule Yayınları.

Johnson, A. (2014). Foucault: Critical theory of the police in a neoliberal age. Theoria, 61(141), 5-29.

Kosotieti, P. (1987). From Collectivity to Individualism in the Welfare State? Acta Sociologica, 30(3-4), 281-293.

Luhmann, N. (2002). Refah Devletlerinin Siyaset Teorisi, Çev. Medeni Beyaztaş, Bakış Yayınları, Istanbul.

Marcuse, H. (2002). One-dimensional Man. Routledge.

Moore, J. (1987). Welfare and dependency. speech to Conservative Constituency Parties Association, September.

Naqvi, S. N. H. (1978). Ethical Foundations of Islamic Economics. Islamic Studies, 17(2), 105136.

Örs, B. (1997). Birey, Toplum ve Devlet İlişkileri Çerçevesinde Yeni İngiliz İdealizmi. İstanbul Üniversitesi Siyasal Bilgiler Fakültesi Dergisi, 16-17-18-19.

Özdemir, S. (2007). Küreselleşme Sürecinde Refah Devleti. İstanbul Ticaret Odası.

Polanyi, K. (2001). The Great Transformation: The Political and Economic Origins of Our Time (2nd bs). Beacon Press.

Pryor, F. L. (1985). The Islamic economic system. Journal of Comparative Economics, 9(2), 197223.

Rosanvallon, P. (2004). Refah Devletinin Krizi.

Rosen, S. (1983). Specialization and Human Capital. Journal of Labor Economics, 1(1), 43-49. 
Sawer, M. (2003). The Ethical State: Social Liberalism in Australia. Melbourne University Press.

Schultz, T. W. (1961). Investment in Human Capital. The American Economic Review, 51(1), 1-17.

Serdar, Y. A. Y. (2014). Tarihsel Süreçte Türkiye'de Sosyal Devlet. 21. Yüzyılda Eğitim Ve Toplum Ĕ̆itim Bilimleri Ve Sosyal Araştırmalar Dergisi, 3(9), 147-162.

Șiddīqī, M. N. (1981). Muslim economic thinking: A survey of contemporary literature. Islamic economics series.

Stone, D. (1989). At Risk in the Welfare State. Social Research, 56(3), 591-633.

Thornton, P. H., \& Ocasio, W. (2008). Institutional logics. The Sage handbook of organizational institutionalism, 840, 99-128.

Topçu, N. (2020). Orwell'ın 1984'ü Çin'de Gerçek Mi Oluyor? Sosyal Kredi Sisteminin Geçmişi, Bugünü ve Geleceği. Insan ve Sosyal Bilimler Dergisi, 3(2), 684-695.

Toprak, D. (2015). Uygulamada Ortaya çikan farkli refah devleti modelleri üzerine bir inceleme. Süleyman Demirel Üniversitesi Sosyal Bilimler Enstitüsü Dergisi, 21, 151-175.

Townshend, J. (1990). J.A. Hobson. Manchester University Press.

Wahl, A. (2015). Refah Devletinin Yükselişi ve Düşüşü (H. Ünal \& B. Öztürk, Çev.). h2o Kitap.

Weiler, P. (1972). The New Liberalism of LT Hobhouse. Victorian Studies, 16(2), 141-161.

Wolf, B. M., \& Wright, L. (2014). Designing Curriculum for Real-World International Business Needs. Journal of Teaching in International Business, 25(3), 165-184. https://doi.org/10.1080/08975930.2014.925740 


\section{Extended Abstract}

The welfare state is a phenomenon that has always been discussed over what the state should do. We can argue that the welfare state started to play a role as a regulatory and interventionist actor as a central force in personal and social relations. It aims to deliver services to the citizens in a more equitable way through the redistribution mechanism instead of leaving it to the market.

The welfare state trains both "citizens" who will obey the rules within its borders and "workers" who will contribute to welfare production, thanks to the centrally controlled institutions, especially education. Thus, the welfare state, as an actor positioned against the market, has created a central power and, in return for the welfare it offers, has the power to intervene in the lives of citizens -indirectly or directly- both to ensure the continuation of this welfare order and to maintain its central power. As a result of this, welfare states produce citizens who are dependent on the state. However, citizens who can live their lives without any problems thanks to the opportunities offered by the welfare state must obey and renounce their freedoms -significantly- to have these opportunities since they have to be good citizens.

There are two main objectives of this study. The first objective is to explore the basic structure of the welfare state and the consequences of this structure for society. The second objective is to conduct a critical analysis of the welfare state in terms of Islamic economics through the concepts of emancipation and empowerment. As part of the second objective, the redistribution mechanism in Muslim societies and how institutions such as zakat, charity and sacrifice make a difference in the context of the welfare state and, ultimately, social relations are examined. With this study, the welfare state, which has been the focus of discussions in recent years, will be examined from the perspective of Islamic economics.

The welfare state model has been seen as an ideal model by the researcher in Islamic economics for a long time. However, if this Islamic model is criticized through the concepts of emancipation and empowerment, some of the features that carry the welfare state examples to the top in the Islamic indices appear to play a key role in raising individuals who must prioritize being a good citizen instead of a Muslim who puts being a servant of God in the center of life, which Islam foresees. The underlying reason for this is that to benefit from welfare states' services; it is necessary to be a good citizen as stipulated by the state.

In the context of this study, we touched upon two main points that enable individuals to be good citizens. The first is that welfare states can centrally control the redistribution mechanism and determine to whom and how welfare will be delivered. In this way, for an individual to receive his share of welfare, he must comply with the definition of a good citizen of the welfare state, that is, an individual who obeys the laws of the state and participates in the capitalist market system as a productive input if there is no obstacle. Secondly, through the educational opportunities offered free of charge by the welfare state, namely the school institution, individuals are trained to be good citizens from an early age and internalize the requirements of being a good citizen. Being an obedient citizen with an extrinsic motivation or an internal 
motivation internalized through the school institution to get a share of welfare means that individuals give up their freedoms to a significant extent.

While centrally provided welfare significantly deprives individuals of their freedom, many needs such as education, health and financial support are provided by the state; It prevents civil society from forming an organized power independent of political authority and individuals from forming an autonomous space independent of the opportunities offered by the state. For this reason, individuals get their power through the opportunities offered by the state as a result of being good citizens. In other words, they become powerful to the extent that they are good citizens. Apart from this, there is no question of having a civilian force field independent of the state.

Citizens, who have become individuals deprived of freedom and power, can only voice any criticism and challenge that they will attempt within the welfare state, within the current modern paradigm, which is a product of enlightenment. For this reason, an act to be a servant of Allah will be acceptable as long as it is compatible with the definition of citizenship.

However, in the political administration envisioned by Islamic economics, it is essential that Muslims are not deprived of their freedom and left in a powerless position. It is only in such a society that Muslims can act without hesitation when confronted with something considered oppressive by an Islamic order, even if that is not seen as good or necessary by the welfare state. In order to achieve this, educational and judicial institutions, which should be built in a social structure with Islamic features, must provide opportunities that will not be dependent on central power and must have institutions that would equip Muslims with the necessary knowledge, skills and power to be servants of Allah.

The main purpose of this article is to reveal the negative aspects of the welfare state model, which will be considered ideal in terms of analysis to be made by focusing on social welfare when it is considered in terms of concepts such as emancipation and empowerment. Thus, the welfare state is evaluated beyond the opportunities it offers. In further studies, empirical studies can be conducted on the examples of different welfare states, and the daily life consequences of the criticisms made here can be investigated. 